Proposed Reforms to the Exogenous Shocks Facility 
INTERNATIONAL MONETARY FUND

\section{Proposed Reforms to the Exogenous Shocks Facility (ESF)}

Prepared by the Policy Development and Review, Legal, and Finance Departments (In consultation with other departments)

Approved by Mark Allen, Sean Hagan, and Andrew Tweedie

July 25,2008

Contents

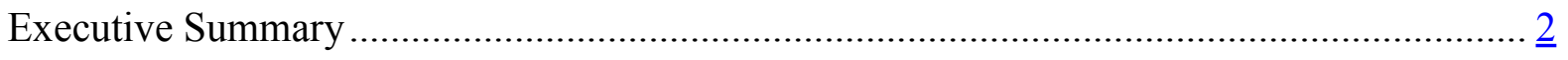

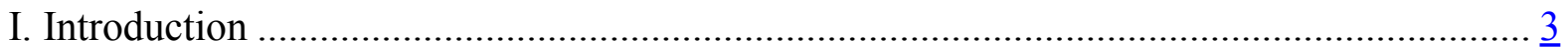

II. Reasons for the Lack of ESF Use..................................................................................

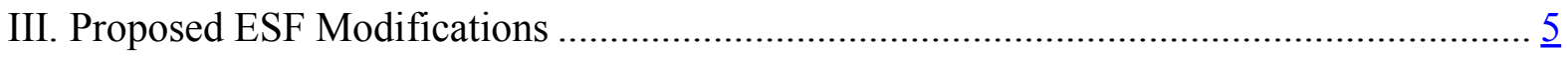

A. Elements of a Modified ESF ......................................................................... $\underline{5}$

B. Relationship with Other Facilities and Instruments ............................................. $\underline{8}$

C. Resource Availability for the Modified ESF....................................................... 10

IV. Approval Requirements, Next Steps, and Issues for Discussion...................................... 11

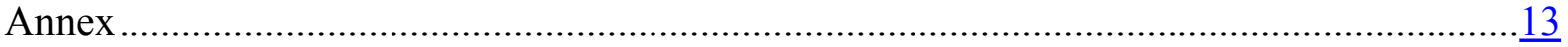

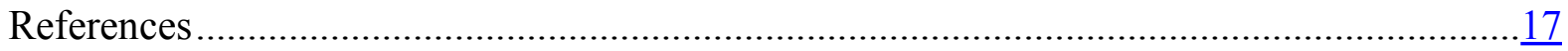




\section{EXECUTIVE SUMMARY}

- The review of the ESF is being accelerated in light of experience and worsening global economic conditions, in particular the surge in food and fuel prices. Despite having become effective in 2006, the ESF has yet to be used. Recent discussions with creditors, donors, potential users, and outside observers have highlighted a number of ways to enhance its effectiveness.

- In responding to the changing global environment, and the views of potential users and donors, the paper identifies a number of principles to guide the reform of the ESF. It suggests that the Fund's shocks financing should: (i) be provided more rapidly (ii) be based on streamlined conditionality focused on addressing the exogenous shock; (iii) provide higher access, and; (iv) better complement other Fund instruments.

- Building on these principles, the paper suggests ways to make the ESF faster and easier to use, and with higher access, by proposing:

- (i) the establishment of a new rapid-access component, with the following key characteristics:

- $\quad$ Available to all Poverty Reduction and Growth Facility (PRGF)-eligible members with a balance of payments (BOP) need whose primary source is an exogenous shock; access limited to 25 percent of quota per shock, to be provided normally in a single tranche, and with no requirement for upper-credit tranche (UCT) standards. A request could be issued to the Board soon after a member's indication of the need for support.

- (ii) modifications to create a high-access component similar to the current ESF, which could be used in particular following a rapid-access component in cases where a member requests more resources than are available under the rapidaccess component. It could also be used on a stand-alone basis. It would be available for the same BOP need as the rapid-access component, with the following key characteristics:

- $\quad$ access would normally be up to 75 percent of quota per arrangement, provided in the context of a one-to-two year program that would need to be of UCT quality. The time required before resources are disbursed would likely be greater than under the rapid-access component, in light of the need to reach understandings on a UCT quality economic program.

- (iii) adjustments that would facilitate use of the modified ESF in conjunction with some other Fund facilities and instruments. 


\section{INTRODUCTION}

1. The modified ESF proposed in this paper aims to meet the needs of low-income members for rapid and useful shocks assistance. The proposals seek to reform the ESF by providing assistance more quickly and with more streamlined conditionality, in amounts sufficient to help members cope with shocks, and in a way that is better integrated with other Fund facilities and instruments.

2. The ESF was approved in late 2005 to enhance the Fund's ability to help lowincome member countries deal with sudden and exogenous shocks. ${ }^{1}$ Discussions leading up to approval of the ESF stressed the vulnerability of developing countries to shocks. ${ }^{2}$ While countries with PRGF arrangements could request augmentations, it was judged that the Fund's low-income members without a PRGF arrangement could benefit from a facility that provided shorter-term assistance in response to an exogenous shock but on PRGF financial terms to avoid the higher costs of borrowing associated with financing from other facilities. ${ }^{3}$

\section{Review of the ESF is being accelerated in light of experience and worsening} global economic conditions. ${ }^{4}$ This paper reviews the ESF somewhat earlier than required given the lack of use to date and a desire to ensure that the Fund has the ability to provide rapid and effective shocks assistance, particularly because surging food and fuel prices could result in an increased need of low-income members for financial support.

\section{ESF modifications are being considered in the context of a broader review of} Fund facilities and consideration of the Fund's role in low-income countries. Although the ESF review is being conducted before the broader facilities review, proposed changes to the ESF are considered with the objectives of that review in mind. This review is also consistent with the discussion laid out in the paper on The Role of the Fund in Low-Income Countries. ${ }^{5}$ Relatedly, proposals to simplify the concessional financing framework will be presented in the context of the general review of Fund facilities.

\footnotetext{
${ }^{1}$ The ESF became effective in January 2006.

${ }^{2}$ IMF 2005a, b, c, and d.

${ }^{3}$ Emergency Assistance is provided through the GRA and is subject to credit tranche terms, including the repurchase period (31/4 - 5 years) and rate of charge. For PRGF-eligible countries, however, bilateral subsidy resources are provided from an administered account that reduce the rate of charge to 0.5 percent per annum, subject to the availability of resources.

${ }^{4}$ In approving establishment of the ESF in late 2005, the Executive Board called for a review of experience under the facility three years after its effective date. This schedule was subsequently extended in the omnibus decision extending review deadlines, and is now only required at five year intervals: at the time, the next ESF review was scheduled for 2009. See Decision No. 13814-(06/98), November 15, 2006.
}

${ }^{5}$ IMF 2008a. 
5. The paper is organized as follows. Section II explores the factors that may have contributed to the lack of use of the ESF to date, Section III outlines a proposal to modify the ESF, including potential demand and resource availability, and Section IV outlines next steps and issues for discussion. The proposed decisions to effect the ESF reforms will be circulated to the Board in a supplement to this paper.

\section{REASONS FOR THE LACK OF ESF USE}

6. The ESF has not been used to date, reflecting three broad factors. First, the economic environment for many LICs has, until recently, been relatively benign. Second, for many countries affected by shocks other sources of Fund financing were available, for example the PRGF and Emergency Natural Disaster Assistance (ENDA). Third, some elements of the ESF's design made it less attractive to potential users.

7. While the economic environment has, until recently, been benign, demand for shocks assistance from the Fund is likely to rise in the period ahead. The recent period of strong economic growth and demand for developing country commodity exports was coupled with stronger capital inflows and, in many cases, debt relief, that helped to offset increased import costs due to higher oil prices. This enabled many countries to maintain or even build foreign exchange reserve holdings. ${ }^{6}$ Despite this, the impact of surging prices for oil (which surpassed the previous December 1979 record high in constant dollars in March 2008, and exceeded $\$ 145$ per barrel in July), and food (which have risen by 50 percent since end-2006) have begun to take their toll. As a result, external balances in some low-income, commodityimporting economies are likely to worsen in 2008, which could contribute to rising external vulnerabilities and demand for shocks assistance from the Fund. ${ }^{7}$

\section{Needs arising from recent shocks have been met largely through the PRGF and} ENDA. Currently, 24 of 77 eligible members have PRGF arrangements, which provide balance of payments assistance and can be augmented in the event of a shock. Since late 2007, a growing number of low-income members have received augmentations to their PRGF arrangement, and discussions are underway with a number of others. ${ }^{8}$ Also, one member eligible for a PRGF or ESF, Honduras, recently entered into a program supported by

\footnotetext{
${ }^{6}$ Dudine et al, 2006 and Dorsey et al, 2008.

${ }^{7}$ IMF 2008 b.

${ }^{8}$ Since end-2007, PRGF augmentations have been approved for Benin, Burkina Faso, the Central African Republic, Haiti, and Kyrgyz Republic (as of end-June), and requests for augmentations have come from Madagascar and Grenada. In addition, the new PRGF arrangements for Mali and Niger have access levels higher than initially planned. See also Annex for a description of the limited shock impact and how many of the affected countries received support under the PRGF.
} 
an SBA. ${ }^{9}$ To help cope with the impact of natural disasters, four countries have benefited from ENDA since the policy on subsidization of ENDA to PRGF-eligible countries was established in 2005. PSI users - considered potential ESF candidates when the facility was created - have for the most part enjoyed sufficiently strong external positions such that recent shocks have not led any to request balance of payments support from the Fund.

\section{Discussions with PRGF-ESF Trust creditors, donors, potential users, and} outside observers have highlighted a number of aspects of the ESF's design that could have discouraged its use:

- $\quad$ Speed: There has been a perception that negotiation of an upper credit tranche-quality program to be supported under the ESF could be too slow given the need for rapid assistance.

- Conditionality: The requirements that a country implement a UCT-quality program and have or be in the process of developing a Poverty Reduction Strategy (PRS) may be unnecessary hurdles for a facility intended to help with short-term stabilization in response to a shock.

- $\quad$ Access: It was perceived that the amount of resources available under the ESF was small both in terms of shocks needs and in relation to the requirement for a UCTquality program.

- Relation to other instruments/facilities: PSI countries were expected to be among the likely users of the ESF, but there were concerns that the policy calling for cancellation of a PSI to access the ESF could undermine the positive signal about a country's policies. Also, the ESF is generally not available to countries receiving Emergency Post Conflict Assistance (EPCA) or with Staff-Monitored Programs (SMPs), as such countries normally lack the capacity to implement a program with UCT conditionality standards.

\section{PRoposed ESF Modifications}

\section{A. Elements of a Modified ESF}

10. This paper proposes modifying the ESF to help ensure that it meets the needs of the Fund's low-income members for rapid and effective shocks assistance. In particular, the Fund's shocks financing should: (i) be provided more rapidly; (ii) be based on streamlined conditionality; (iii) provide higher access; and (iv) better complement other Fund instruments. Furthermore, financing to LICs in response to shocks should be provided

\footnotetext{
${ }^{9}$ Economic imbalances, particularly related to public finances and rapid credit growth, grew during 2007 and led Honduras to request an SBA to support a shorter-term stabilization program.
} 
on PRGF financial terms to help avoid risks to debt sustainability. In many instances, Fund access may serve a catalytic role for grants and more concessional loan resources. In this context this paper proposes:

- the establishment of a rapid-access component that would cover any exogenous shock and would be like the current ENDA in many respects. Access would be limited to 25 percent of quota for each shock, and resources would normally be provided in a single disbursement. This component would not require upper credit tranche quality policies.

- $\quad$ modifications to create a high-access component that would also cover any exogenous shock and would be like the current ESF in key respects. It could be used in particular following a rapid-access component in cases where a member requests more resources than are available under the rapid-access component. It could also be used on a stand-alone basis. Access would normally be up to 75 percent of quota for each arrangement, ${ }^{10}$ and resources would be provided in multiple disbursements subject to reviews. This component would require a program of UCT quality. ${ }^{11}$

\section{The rapid-access component of the modified ESF would have the following key characteristics:}

- $\quad$ Eligibility and qualification: To qualify, a PRGF-eligible member must have a balance of payments need whose primary source is an exogenous shock. ${ }^{12}$ The requirement under the current ESF that a shock be "sudden" would be eliminated. Doing so would clarify that shocks that develop over a longer period and create an actual balance of payments need, such as the current increase in food and fuel prices, could provide a basis for financing. Shortfalls in aid or domestic policy slippages would not be covered.

- $\quad$ Access: Up to 25 percent of quota per shock, normally in a single outright disbursement. The level of access in any particular case would take into account a number of factors: the size and likely persistence of the shock; the balance of payments need; the member's economic position and short-term policy commitments;

\footnotetext{
10 The access limit would be less any outstanding rapid-access disbursements for the same shock.

${ }^{11}$ By virtue of the exposure, a UCT-quality program would be required in all cases under the high-access component.

${ }^{12}$ The ENDA criterion that the member be unable to meet immediate financing needs without serious depletion of its reserves would not apply. In addition, there would be a presumption against repeated disbursements under the rapid-access component over a short period, and for moving to the high-access component or a PRGF arrangement. However, repeated use of the rapid-access component could be considered in rare cases where separate shocks occur.
} 
the amount of outstanding Fund credit; the record of payments; capacity to repay; and the likelihood of additional donor assistance.

- $\quad$ Policy commitments and approval standards: As under ENDA, understandings will be needed to ensure that inappropriate policies will not compound the problems caused by the shock, and the member will be required to outline the policies it plans to pursue, including its intention to avoid introducing or intensifying exchange and trade restrictions. The request will be granted when the Fund is satisfied that the member will cooperate with the Fund in an effort to find, where appropriate, solutions for its BOP difficulties. The member might be requested to implement up-front measures as a condition for use of the financing, including in cases where this is needed to confirm that the approval criteria are in place.

- Speed of access: Approval of assistance under the rapid-access component could be based on a letter outlining a member's policy commitments and/or actions already taken rather than a negotiated program. As such, it is likely that a request could be issued to the Executive Board soon after the member's indication of the need for support, as in many cases no mission would be needed.

- $\quad$ PRS requirements and other policies: A country would not need to have a PRS in place or to develop one. A request for assistance under the rapid-access component will not require a safeguards assessment, consistent with the current policy for ENDA disbursements. The use of ESF resources would count towards the thresholds for post-program monitoring. Other relevant Fund policies would generally apply to the rapid-access component in the same manner as applicable to ENDA.

- $\quad$ Relationship with other facilities and instruments: The rapid-access component could be used concurrently with most other Fund facilities or instruments (see Section $B$ for details).

12. Support will also be available to PRGF-eligible members under a high-access component, which could be used in particular following a rapid-access component in cases where a member requests more resources than are available under the rapidaccess component. It could also be used on a stand-alone basis. This component would involve financing under an arrangement and would be similar in key respects to the current ESF, but it would allow for higher access, could cover a wider range of shocks, and would not require a PRS. This component also shares certain characteristics of the rapid-access component outlined above, including the BOP need and coverage of all exogenous shocks, but has the following additional features: 
- $\quad$ Access: Normally up to 75 percent of quota per arrangement, less outstanding amounts disbursed under the rapid-access component for the same shock, to be disbursed normally subject to reviews. ${ }^{13}$ The level of access in any particular case would take into account the same factors outlined above. Augmentation would be possible at the time of reviews under the arrangement if the impact of the shock proves to be larger than expected. A member may not have more than one highaccess ESF arrangement for the same shock.

- Policy commitments and approval standards: The member will have to commit to a one-to-two year upper credit tranche-quality economic program with conditionality limited to macroeconomic and structural measures considered important for adjustment to the shock. ${ }^{14}$

- Speed of access: The time necessary to provide high-access resources will likely be greater than under the rapid-access component, in light of the time necessary to reach understandings on an appropriate program.

- Other policies: The high-access component will have the same basic modalities and other policy requirements as arrangements under the current ESF. In particular: (i) the high-access component will be governed by the current ESF provisions on performance criteria, reviews and other modalities, (ii) a member would need to have a safeguards assessment completed at least by the time of the first program review, (iii) the high-access component would count towards the policy on longer-term program engagement, (iv) a high-access component would provide Fund support for a program of upper credit tranche-quality and thus, could count toward a track record of performance for HIPC Initiative purposes. ${ }^{15}$

\section{B. Relationship with Other Facilities and Instruments}

\section{The modified ESF could be used more flexibly in conjunction with other Fund} facilities and instruments. A more flexible ESF would strengthen the Fund's ability to provide financing for members with a temporary BOP need arising from a shock. Nevertheless, members facing protracted balance of payments problems (also potentially

\footnotetext{
${ }^{13}$ The ESF currently has a normal limit of 50 percent of quota for all access, not only per arrangement.

${ }^{14}$ As under the current ESF, an arrangement under the high-access component will normally be approved only if the Fund determines that, in order to adjust to the shock, the member does not need to implement structural reforms of the type that would normally be supported by a PRGF arrangement.

${ }^{15}$ The supplement with the draft decisions will address in greater detail the application of current ESF provisions and UFR policies to the rapid- and high-access components.
} 
arising from a shock), and that require longer-term reforms, would continue to be supported under the PRGF.

\section{The rapid-access component can be used concurrently with other Fund facilities or instruments, such as the PSI, EPCA, SMPs, or an off-track PRGF:}

- A member would be able to maintain its PSI while receiving support under the rapidaccess component. ${ }^{16}$

- $\quad$ The lack of a UCT conditionality requirement means that members lacking capacity to implement a UCT-quality program (e.g., those with SMPs or receiving EPCA) could nevertheless qualify for support under the rapid-access component.

- A member with an off-track PRGF arrangement that required financing to address an exogenous shock could request rapid-access support if the approval criteria were met. The PRGF arrangement would not need to be cancelled. ${ }^{17}$

\section{The high-access component could be used concurrently with a PSI:}

- $\quad$ The current policy would be modified so as to allow a member to maintain its PSI while receiving support under the high-access component. ${ }^{18}$ This would provide members that value the positive signal of a PSI the opportunity to retain that form of engagement despite a temporary shock that creates a short-term financing need i.e., to avoid sending a negative signal as a result of the PSI lapsing. In such circumstances, an existing PSI-supported program would provide a basis for ESF discussions, and a high-access ESF arrangement could run concurrently with a PSI, although the PSIsupported program would be adjusted in light of the shock.

- $\quad$ Additional financing needs of a member with a PRGF arrangement would be met through a PRGF augmentation, but not through high-access ESF support. A member

\footnotetext{
${ }^{16}$ For a member that has successfully completed its most recent PSI review, the request for a rapid-access drawing could simply reaffirm the member's policy commitments by reference to the PSI, hence resources could be provided very quickly. Modification of a PSI-supported program would not be necessary in all cases, but would be appropriate if the shock is likely to affect a country's ability to meet PSI program targets.

${ }^{17}$ The PRGF-ESF Trust Instrument currently provides that members may not obtain assistance under the PRGF and ESF at the same time.

${ }^{18}$ Concurrent PSI/high-access ESF arrangements would have modalities akin to those under blends-with one set of program documentation, one set of program targets, one review schedule etc. Regarding the review schedule, it is proposed that approval of a high-access ESF arrangement would shift PSI reviews from the "regular review cycle" of a stand-alone PSI to the more flexible review cycle applicable to PRGF/ESF arrangements. Other requirements under the PSI would generally continue to apply, however, including the requirement that the member have a PRS.
} 
with an off-track PRGF arrangement that wished to obtain support under the highaccess component would need to cancel its PRGF arrangement

- $\quad$ Support under the high-access component would not normally be available to countries receiving EPCA or with SMPs in light of the requirement of UCT conditionality standards.

\section{Resource Availability for the Modified ESF}

16. The adequacy of the Fund's concessional resources was last discussed in the regular update paper issued in April. ${ }^{19}$ Available loan and subsidy resources are currently estimated at SDR 2.7 billion and SDR 1.4 billion, respectively. ${ }^{20}$ Of the available subsidy resources, it is estimated that SDR 0.6 billion would be needed to cover existing PRGF arrangements, and the remaining subsidy resources of SDR 0.8 billion could support new lending of about SDR 3.2 billion.

\section{It is difficult to project the demand for the modified ESF, which would depend} on the number of countries, size of their respective quotas, and the level of access requested. If all PRGF-eligible countries requested 25 percent of quota under the modified ESF or augmentation of existing PRGF arrangements, ${ }^{21}$ this would entail new lending of SDR 2.9 billion. Under a different scenario, assuming all countries with existing PRGF arrangements sought augmentations of 15 percent of quota (the average of recent cases) and only a quarter of the remaining countries sought access of 75 percent of quota under the modified ESF, demand for new lending would be about SDR 2 billion.

18. The expectation is that there would be little need for use of ENDA (and its less concessional financing terms) by low-income members. With largely similar policy requirements to ENDA and greater concessionality under the PRGF-ESF Trust, ${ }^{22}$ the rapidaccess ESF would effectively replace ENDA drawings from the GRA for PRGF-eligible

\footnotetext{
${ }^{19}$ International Monetary Fund, 2008, Update on the Financing of the Fund's Concessional Assistance and Debt Relief to Low-Income Member Countries.

${ }^{20}$ Includes those committed but not yet received.

${ }^{21}$ India and the three arrears cases (Somalia, Sudan, and Zimbabwe) are excluded from all projections of potential demand.

${ }^{22}$ As noted earlier, the rate of charge on ENDA financing to PRGF-eligible countries is subsidized with bilateral resources to a rate of 0.5 percent per annum, subject to the availability of subsidy resources. Despite this interest rate subsidy, however, the shorter repurchase period applicable to ENDA renders it less concessional than assistance provided through the PRGF-ESF Trust.
} 
members hit by natural disasters. ${ }^{23}$ With the rapid- and high-access ESF components in place, there would also be little reason why a PRGF-eligible member would need to consider nonconcessional drawings under an SBA or the CFF in response to exogenous shocks. ${ }^{24}$

19. Once the existing subsidy resources are exhausted, the Board could approve the use of resources in the Reserve Account of the PRGF-ESF Trust for subsidizing concessional lending. This "self-sustained" operation could be initiated earlier than discussed in the previous update paper. Additional loan resources would need to be mobilized should demand for concessional assistance remain high.

\section{ApProval Requirements, NeXt Steps, AND IsSUes FOR Discussion}

\section{The draft decisions to effect the above proposals will be circulated in a}

supplement to the current paper. These decisions will include, among others, amendments of both the PRGF-ESF Trust Instrument and the PSI decision (the latter to reflect the revised modalities being proposed for cases where a PSI runs in parallel with a high-access ESF arrangement). The decision amending the PRGF-ESF Trust Instrument will require adoption by an 85 percent majority of the total voting power, as certain aspects of the amendment would require a change in the "purposes" clause of the ESF, and thus a change in the purposes for which Special Disbursement Account (SDA) resources in the PRGF-ESF Trust may be used. Specifically, the ESF purposes clause would need to be amended (i) to delete the requirement that support be provided only for programs to facilitate adjustment to a shock (as discussed above, rapid-access support does not necessarily require an adjustment program), and (ii) to delete the requirement that covered shocks be "sudden". ${ }^{25}$ Moreover, as the purposes clause is a "protected" provision in the PRGF-ESF Trust, the consent of all

\footnotetext{
${ }^{23}$ ENDA would remain a special GRA policy and thus would be available to PRGF-eligible members-all Fund members can request assistance through the GRA. Given the concessionality differential between ENDA and the ESF, however, there would be little reason for a PRGF-eligible member to consider ENDA.

${ }^{24}$ With requirements that have contributed to infrequent use of the CFF, the facility might be considered for elimination in the broader facilities review. CFF-type shocks affecting middle-income countries could thereafter be addressed exclusively under SBAs.

${ }^{25}$ The ESF "purposes" clause is Section I, paragraph 1(b)of the PRGF-ESF Trust Instrument. Regarding SDA resources, the PRGF-ESF Subsidy Account is funded in part with SDR 400 million transferred from the SDA in 1994, and SDR 470 million transferred from the SDA in early 2006 in the context of the MDRI; while the Reserve Account is funded exclusively with SDA-related resources. The use of SDA resources in the PRGFESF Trust is pursuant to Article V, Section 12(f)(ii), which authorizes the Fund to provide balance of payments assistance on special terms to developing members, but requires an 85 percent majority of the total voting power for decisions authorizing such use.
} 
contributors to the Loan and Subsidy Accounts of the PRGF-ESF Trust will also be needed before the Board decision could become effective. ${ }^{26}$

\section{Following Board approval of the proposed decisions, staff will undertake an} outreach effort with low-income members who could be interested in such support. Staff will also update the relevant staff guidance notes (including those on the ESF and PSI) to bring them in line with the new decisions. As noted above, the decision amending the ESF would only become effective upon receipt of contributors' consents.

\section{Directors may want to indicate their views on the following issues:}

1) Do Directors agree that the ESF should be modified to meet the needs of low-income members better, by providing more, and more rapid, financing, and by making it easier to use?

2) Do Directors agree that the ESF should be modified by creating rapid and high-access components with the modalities outlined?

\footnotetext{
${ }^{26}$ The ESF purposes clause is among the protected provisions listed in Section IX of the PRGF-ESF Trust Instrument. For a detailed discussion of protected provisions and contributor consent requirements, see, IMF $2005 \mathrm{e}$ and $\mathrm{f}$.
} 


\section{ANNEX \\ Shocks to PRGF-Eligible Countries in 2006-2008}

In 2006-2007, only a few PRGF-eligible countries were exposed to severe terms of trade and/or large demand shocks, but it is likely that many will be in 2008. As shown in Table 1, in 2006, the terms of trade deteriorated in 38 out of 77 PRGF-eligible countries, in 2007 they deteriorated in 49 countries, and in 2008 they are expected to deteriorate in 46 countries. Moreover, with the increases in food and fuel prices 2007 and 2008, many low-income countries are facing a very large cumulative shock over these years (not shown in the Table). Furthermore, over the period, the number of countries experiencing a large or severe terms of trade shock increases from 15 in 2006 to 18 in 2008. Similarly, the number of countries experiencing a large or severe drop in the real GDP growth of trading partners increases from 0 in 2006 to 18 in 2008. Finally, in 2008 six countries are expected to experience large or severe terms of trade and demand shocks at the same time, compared to no such cases in 2006.

Table 1: Number of PRGF-eligible countries affected by adverse terms of trade and demand shocks, 2006-2008 ${ }^{1 /}$

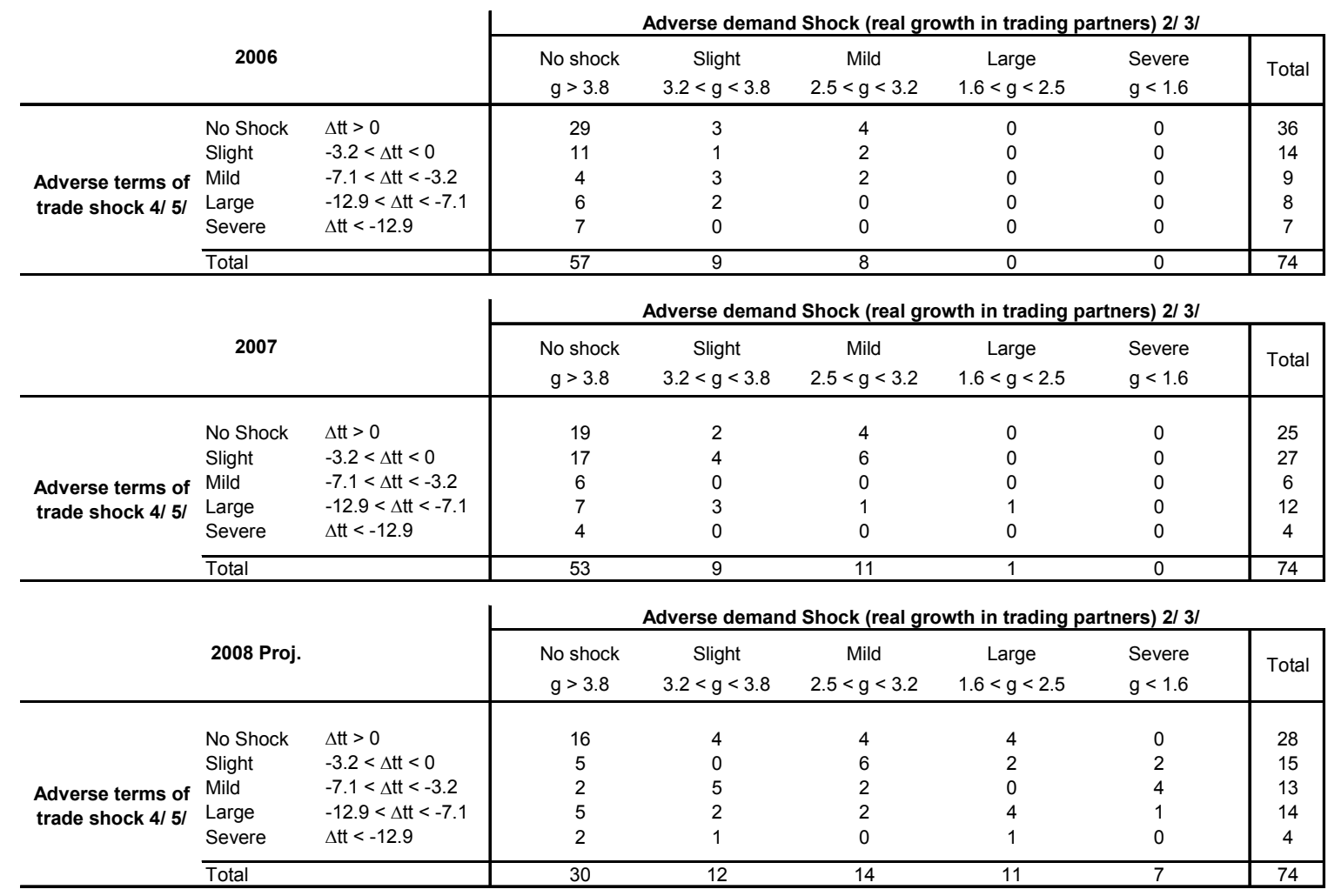

Source: WEO data and projections

1/ Excludes Liberia, Somalia, and Tonga for lack of data on terms of trade on goods and services, and Timor-Leste for lack of data on demand from trading partners. For the Democratic Republic of Congo and Nepal, the terms of trade on goods is used.

2/ The thresholds correspond to the quartiles of the distribution of real growth of PRGF-eligible countries' trading partners, conditional on this growth being below the historical median over 1995-2005.

$3 / \mathrm{g}$ indicates the rate of growth of trading partners, in percent.

4/ The thresholds correspond to the quartiles of the distributions of adverse terms of trade shocks for all PRGF-eligible countries, over 1995-2005.

$5 / \Delta \mathrm{tt}$ indicates the change in the terms of trade, in percent. 


\section{Many countries that experienced a severe terms of trade shock or a large demand shock} in 2006 or 2007 had a PRGF-supported program; but this share is expected to decline in 2008. As shown in Table 2, in 2006 and 2007, just under half of the countries that experienced a large or severe terms of trade or demand shock had a PRGF in place. However, in 2008 the number of such countries dropped to about a third. No countries with PSIs were hit by large or severe terms of trade or demand shocks in 2006 and 2007, but half of them are expected to be hit by such shocks in 2008. Finally, in 2006, 2007, and 2008, two, seven, and three countries, respectively, did not have a PRGF and were affected by a natural disaster which caused estimated damages over 0.5 percent of GDP.

Table 2: Program status by shocks in PRGF-eligible countries, 2006-2008 1/

\begin{tabular}{|c|c|c|c|c|c|c|c|c|c|c|c|c|c|c|c|c|}
\hline \multirow[b]{2}{*}{2006} & \multicolumn{5}{|c|}{ Adverse terms of trade shock $2 / 3 /$} & \multicolumn{5}{|c|}{$\begin{array}{l}\text { Adverse demand Shock (real growth in trading } \\
\text { partners) } 4 / 5 /\end{array}$} & \multicolumn{5}{|c|}{$\begin{array}{l}\text { Damage caused by natural disaster, in percent } \\
\text { of GDP } 6 /\end{array}$} & \multirow[b]{2}{*}{ Total } \\
\hline & 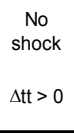 & $\begin{array}{c}\text { Slight } \\
-3.2<\Delta \mathrm{tt} \\
<0\end{array}$ & $\begin{array}{c}\text { Mild } \\
\\
-7.1<\Delta \mathrm{tt} \\
<-3.2\end{array}$ & $\begin{array}{c}\text { Large } \\
-12.9<\Delta \mathrm{tt} \\
<-7.1\end{array}$ & $\begin{array}{c}\text { Severe } \\
\Delta t t<- \\
12.9 \\
\end{array}$ & $\begin{array}{l}\text { No shock } \\
g>3.8\end{array}$ & $\begin{array}{l}\text { Slight } \\
\\
3.2<\mathrm{g} \\
<3.8 \\
\end{array}$ & \begin{tabular}{l}
\multicolumn{1}{c}{ Mild } \\
$2.5<\mathrm{g}$ \\
$<3.2$
\end{tabular} & $\begin{array}{l}\text { Large } \\
1.6<\mathrm{g} \\
<2.5\end{array}$ & $\begin{array}{l}\text { Severe } \\
\mathrm{g}<1.6\end{array}$ & $\begin{array}{c}\begin{array}{c}\text { No } \\
\text { shock }\end{array} \\
\text { Dam }=0\end{array}$ & $\begin{array}{c}\text { Slight } \\
0<\text { Dam } \\
<0.1\end{array}$ & $\begin{array}{c}\text { Mild } \\
0.1< \\
\text { Dam < } \\
0.5\end{array}$ & $\begin{array}{c}\text { Large } \\
0.5<\text { Dam } \\
<1\end{array}$ & $\begin{array}{l}\text { Severe } \\
\text { Dam }>1\end{array}$ & \\
\hline No program & 20 & 7 & 1 & 5 & 4 & 33 & 2 & 2 & 0 & 0 & 31 & 2 & 2 & 1 & 1 & 37 \\
\hline EPCA/ENDA 7/ & 0 & 1 & 0 & 1 & 0 & 1 & 1 & 0 & 0 & 0 & 2 & 0 & 0 & 0 & 0 & 2 \\
\hline PSI & 2 & 1 & 0 & 0 & 0 & 1 & 0 & 2 & 0 & 0 & 3 & 0 & 0 & 0 & 0 & 3 \\
\hline Total & 36 & 14 & 9 & 8 & 7 & 57 & 9 & 8 & 0 & 0 & 66 & 3 & 2 & 1 & 2 & 74 \\
\hline \multirow[b]{2}{*}{2007} & \multicolumn{5}{|c|}{ Adverse terms of trade shock $2 / 3 /$} & \multicolumn{5}{|c|}{$\begin{array}{l}\text { Adverse demand Shock (real growth in trading } \\
\text { partners) } 4 / 5 /\end{array}$} & \multicolumn{5}{|c|}{$\begin{array}{l}\text { Damage caused by natural disaster, in percent } \\
\text { of GDP 6/ }\end{array}$} & \multirow[b]{2}{*}{ Total 5/ } \\
\hline & $\begin{array}{c}\text { No } \\
\text { shock } \\
\Delta t \mathrm{t}>0\end{array}$ & $\begin{array}{c}\text { Slight } \\
-3.2<\Delta \mathrm{tt} \\
<0\end{array}$ & $\begin{array}{c}\text { Mild } \\
-7.1<\Delta \mathrm{tt} \\
<-3.2 \\
\end{array}$ & $\begin{array}{c}\text { Large } \\
-12.9<\Delta \mathrm{tt} \\
<-7.1 \\
\end{array}$ & $\begin{array}{c}\text { Severe } \\
\Delta t t<- \\
12.9\end{array}$ & $\begin{array}{l}\text { No shock } \\
g>3.8\end{array}$ & $\begin{array}{l}\text { Slight } \\
3.2<\mathrm{g} \\
<3.8\end{array}$ & \begin{tabular}{l}
\multicolumn{1}{c}{ Mild } \\
$2.5<\mathrm{g}$ \\
$<3.2$
\end{tabular} & $\begin{array}{l}\text { Large } \\
1.6<\mathrm{g} \\
<2.5\end{array}$ & $\begin{array}{l}\text { Severe } \\
\mathrm{g}<1.6\end{array}$ & \begin{tabular}{|c|}
$\begin{array}{c}\text { No } \\
\text { shock }\end{array}$ \\
Dam = 0
\end{tabular} & $\begin{array}{c}\text { Slight } \\
0<\text { Dam } \\
<0.1\end{array}$ & $\begin{array}{c}\text { Mild } \\
0.1< \\
\text { Dam < } \\
0.5 \\
\end{array}$ & $\begin{array}{c}\text { Large } \\
0.5<\text { Dam } \\
<1\end{array}$ & $\begin{array}{l}\text { Severe } \\
\text { Dam }>1\end{array}$ & \\
\hline No program & 13 & 16 & 3 & 6 & 2 & 32 & 3 & 5 & 0 & 0 & 29 & 5 & 0 & 2 & 4 & 40 \\
\hline EPCA/ENDA $7 /$ & 1 & 0 & 0 & 0 & 0 & 1 & 0 & 0 & 0 & 0 & 1 & 0 & 0 & 0 & 0 & 1 \\
\hline PRGF & 7 & 10 & 3 & 6 & 2 & 18 & 5 & 4 & 1 & 0 & 23 & 3 & 0 & 0 & 2 & 28 \\
\hline PSI & 4 & 1 & 0 & 0 & 0 & 2 & 1 & 2 & 0 & 0 & 3 & 1 & 0 & 1 & 0 & 5 \\
\hline Total & 25 & 27 & 6 & 12 & 4 & 53 & 9 & 11 & 1 & 0 & 56 & 9 & 0 & 3 & 6 & 74 \\
\hline \multirow[b]{2}{*}{2008 Proj. } & \multicolumn{5}{|c|}{ Adverse terms of trade shock $2 / 3 /$} & \multicolumn{5}{|c|}{$\begin{array}{l}\text { Adverse demand Shock (real growth in trading } \\
\text { partners) } 4 / 5 /\end{array}$} & \multicolumn{5}{|c|}{$\begin{array}{l}\text { Damage caused by natural disaster, in percent } \\
\text { of GDP 6/ }\end{array}$} & \\
\hline & 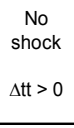 & $\begin{array}{c}\text { Slight } \\
-3.2<\Delta \mathrm{tt} \\
<0\end{array}$ & $\begin{array}{c}\text { Mild } \\
-7.1<\Delta \mathrm{tt} \\
<-3.2 \\
\end{array}$ & $\begin{array}{c}\text { Large } \\
-12.9<\Delta \mathrm{tt} \\
<-7.1 \\
\end{array}$ & $\begin{array}{c}\text { Severe } \\
\Delta t \mathrm{tt}<- \\
12.9\end{array}$ & $\begin{array}{c}\text { No shock } \\
g>3.8\end{array}$ & $\begin{array}{l}\text { Slight } \\
3.2<\mathrm{g} \\
<3.8 \\
\end{array}$ & \begin{tabular}{l}
\multicolumn{1}{c}{ Mild } \\
$2.5<\mathrm{g}$ \\
$<3.2$ \\
\end{tabular} & $\begin{array}{l}\text { Large } \\
1.6<\mathrm{g} \\
<2.5 \\
\end{array}$ & $\begin{array}{l}\text { Severe } \\
\mathrm{g}<1.6\end{array}$ & $\begin{array}{c}\text { No } \\
\text { shock } \\
\text { Dam }=0\end{array}$ & $\begin{array}{c}\text { Slight } \\
0<\text { Dam } \\
<0.1\end{array}$ & $\begin{array}{c}\text { Mild } \\
0.1< \\
\text { Dam < } \\
0.5 \\
\end{array}$ & $\begin{array}{c}\text { Large } \\
0.5<\text { Dam } \\
<1\end{array}$ & $\begin{array}{c}\text { Severe } \\
\text { Dam }>1\end{array}$ & Total 5 \\
\hline No program & 18 & 7 & 7 & 9 & 1 & 17 & 8 & 9 & 7 & 1 & 40 & 0 & 0 & 0 & 2 & 42 \\
\hline EPCA/ENDA & 2 & 2 & 0 & 0 & 0 & 1 & 1 & 1 & 0 & 1 & 4 & 0 & 0 & 0 & 0 & 4 \\
\hline PRGF & 6 & 6 & 4 & 4 & 2 & 10 & 2 & 4 & 2 & 4 & 22 & 0 & 0 & 0 & 0 & 22 \\
\hline PSI & 2 & 0 & 1 & 1 & 1 & 2 & 1 & 0 & 2 & 0 & 4 & 0 & 0 & 0 & 1 & 5 \\
\hline SBA & 0 & 0 & 1 & 0 & 0 & 0 & 0 & 0 & 0 & 1 & 1 & 0 & 0 & 0 & 0 & 1 \\
\hline
\end{tabular}

Source: WEO data and projections, and EM-DAT: The OFDA/CRED International Disaster Database - www.emdat.be, Universite Catholique de Louvain, Brussles (Belgium)

1/ A country is classified as having a program in a particular year if the program expires after June of that year (including because of an extension and even if the program is off-track), or if it is approved before June of that year (Madagascar is classified as having a PRGF in 2006 because the program was approved in July, and the Republic of Congo

is classified as having a PRGF in 2008 although the program expired in June). The table excludes Liberia, Somalia, and Tonga for lack of data on terms of trade

on goods and services, and Timor-Leste for lack of data on demand from trading partners. For the Democratic Republic of Congo and Nepal, the terms of trade on goods is used.

2/ The thresholds correspond to the quartiles of the distribution of real growth of PRGF-eligible countries' trading partners, conditional on this growth being below

the historical median over 1995-2005

$3 / \Delta t t$ indicates the change in the terms of trade, in percent.

4/ The thresholds correspond to the quartiles of the distributions of adverse terms of trade shocks for all PRGF-eligible countries, over 1995-2005

$5 / \mathrm{g}$ indicates the rate of growth of trading partners, in percent.

6/ Over 1995-2005, on annual average, 60 countries experience no shock, 5 a slight shock, 3 a mild shock, 3 a large shock, and 5 a severe shock.

7/ No ENDA was requested in 2006 or 2007. 


\section{Few countries with a terms of trade shock and no program experienced significant} current account deterioration and loss of reserves. As Table 3 shows, in 2006, in 11 out of 17 countries that experienced a terms of trade shock and had no program, and in 14 out of the 21 countries that experienced a terms of trade shock but had a program, the shock could have caused, ex ante, a loss of reserves greater than 0.5 months of the same year imports of goods and services. However, only four countries with a terms of trade shock and no program turned out to suffer such a loss, and only three countries with a terms of trade shock and a program suffered such a loss. Similarly, in 2006, the current account worsened by more than 2 percent of GDP in only three of the 17 countries with a terms of trade shock and no program, and in only three of the 21 countries with a shock and a program. A similar pattern emerges for 2007 and is projected to emerge in 2008. 
Table 3: Ex ante and Ex post reserve loss, and ex post change in current account balance for PRGF-eligible countries with a terms of trade shock, 2006-2008 ${ }^{1 /}$

PRGF-eligible countries with no program

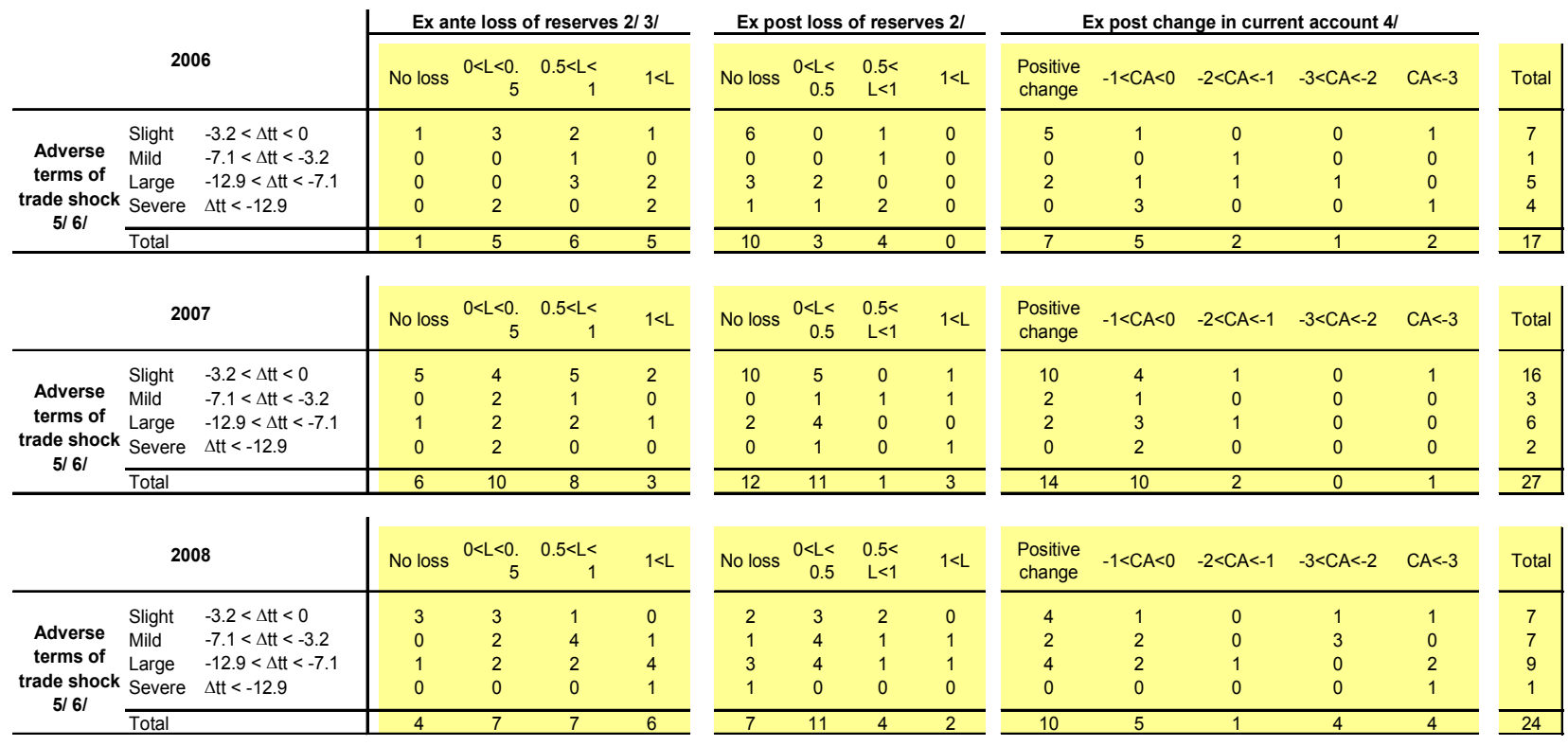

PRGF-eligible countries with a program

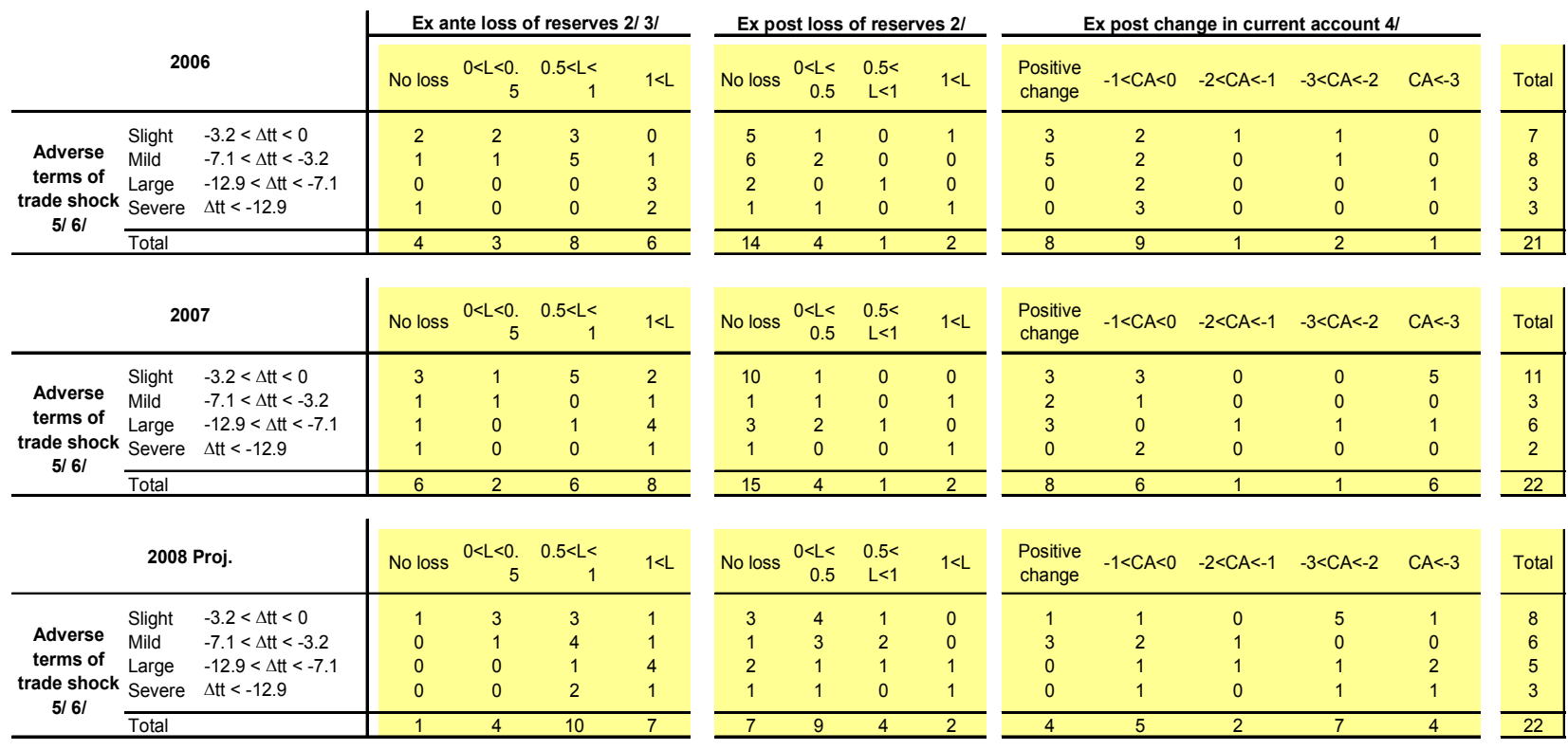

Source: WEO data and projections.

1/ Excludes Liberia, Somalia, and Tonga for lack of data on terms of trade on goods and services, and Timor-Leste for lack of data on demand from trading partners. For the Democratic Republic of Congo and Nepal, the terms of trade on goods is used.

2/ In months of same year imports of goods and services ( $L$ indicates the reserve loss)

$3 /$ The ex ante reserve loss is computed assuming no change in service imports, and assuming that the change in gross reserves equals the change in the value of

exports and imports of goods. The change in the value of exports and imports of goods is computed assuming no demand elasticities, and using the deflators of

exports and imports of goods.

4/ In percent of GDP

5/ The thresholds correspond to the quintiles of the distributions of all negative terms of trade shocks over 1967-2005

$6 / \Delta t \mathrm{t}$ indicates the change in the terms of trade, in percent. 


\section{References}

International Monetary Fund, 2005a, Establishment of an Exogenous Shocks Facility Under the Poverty Reduction and Growth Facility Trust, Washington, DC.

International Monetary Fund, 2005b, The Chairman's Summing Up-Establishment of an Exogenous Shocks Facility Under the Poverty Reduction and Growth Facility Trust, Washington, DC.

International Monetary Fund, 2005c, Strengthening the Fund's Ability to Assist Low-Income Countries Meet Balance of Payments Needs Arising from Sudden and Exogenous Shocks, Washington, DC.

International Monetary Fund, 2005d, The Chairman's Summing Up-Strengthening the Fund's Ability to Assist Low-Income Countries Meet Balance of Payments Needs Arising from Sudden and Exogenous Shocks, Washington, DC.

International Monetary Fund, 2005e, The Multilateral Debt Relief Initiative (G-8 Proposal) and Its Implications for the Fund - Further Considerations-Supplemental Information, Washington, DC.

International Monetary Fund, 2005f, The G-8 Debt Cancellation Proposal and Its Implications for the Fund-Further Considerations, Washington, DC.

International Monetary Fund, 2008a, The Role of the Fund in Low-Income Countries, Washington, DC.

International Monetary Fund, 2008b, Food and Fuel Prices-Recent Developments, Macroeconomic Impact, and Policy Responses, Washington, DC.

Dorsey, Thomas William, Helaway Tadesse, Sukhwinder Singh, and Zuzana Brixiova, The Landscape of Capital Flows to Low-Income Countries, IMF Working Paper 08/51 (Washington: International Monetary Fund).

Dudine, Paolo, James John, Mark Lewis, Luzmaria Monasi, Helaway Tadesse, and Joerg Zeuner, Weathering the Storm So Far: The Impact of the 2003-05 Oil Shock on LowIncome Countries, IMF Working Paper 06/171 (Washington: International Monetary Fund). 